\title{
ABO BLOOD GROUPS AND ACUTE BIOLOGIC FALSE POSITIVE SEROLOGICAL TESTS FOR SYPHILIS*
}

BY

\author{
A. I. MORRISON \\ Royal Hospital, Sheffield
}

Detre (1906) first reported the application of the complement-fixation test of Bordet and Gengou to the diagnosis of human syphilis. 2 weeks before this Wassermann, Neisser, and Bruck (1906) had published their observations on the sero-diagnosis of experimental syphilis in monkeys. Saline extracts of syphilitic tissues were used in the preparation of antigens which were thought to be specific due to the treponemes which they contained.

Later it was found that antigen could be prepared from normal tissues. The tests, therefore, are nonspecific. Reagin, which was thought to develop in those suffering from treponemal diseases, was found to be present in minute amounts in most, if not all, normal persons. It is this non-specific property which may give rise to the anomalous results sometimes obtained in the serological tests for syphilis and the need for a battery of tests to obviate diagnostic difficulties. That positive serological results were obtained in persons not infected with syphilis was recognized more than 50 years ago. Bruck (1911), in a monograph on the pathology and treatment of syphilis, contributed a chapter on the false positive reaction of the Wassermann test.

A biologic false positive (BFP) reaction is a positive reaction, not due to technical error, given by a serological test for syphilis using a lipoid antigen with the serum of a patient not infected by pathogenic treponemes. The BFP reaction is generally classified as acute or chronic. The acute BFP reaction is associated with non-syphilitic conditions and occurs during, or soon after, an acute infection or immunization, it disappears spontaneously after days or weeks, or within 6 months. The chronic BFP reaction persists for months or years, or for life. No precipitating cause can be found; the titre is usually low and, as with the acute variety, there are discrepancies between individual tests.

Moore (1956), in his group of BFP reactors, all of whom were white, found that most were under 30 years of age and 70 per cent. were women. Both

* Received for publication July 9, 1965.
Moore and later Catterall (1961) found that the chronic BFP reaction may be of grave prognostic importance, a proportion of these patients developing some form of collagen disease.

Pregnancy is a physiological condition which is sometimes associated with the spontaneous appearance of an acute BFP reaction, but the incidence is exceedingly small. King $(1964$, p. 206) states that in primiparae the incidence of positive serological tests for the years 1953 to 1961 varied from 0.08 per cent. of 61,606 cases to $0 \cdot 28$ per cent. of 48,420 cases. In multiparae, for the same period, the figures, given only as a percentage, varied from 0.14 to 0.43 per cent. From these figures, therefore, the total number of cases of positive serological tests in antenatal patients for England and Wales for a period of 9 years was only 8,802 .

Wilkinson and Sequeira (1955) reported on 244 pregnant women with positive STS; of these, $27 \cdot 5$ per cent. had a negative TPI and would be considered BFP reactors. The British Cooperative Clinical Group (1959) reported on 219 similar cases, of these, 23.3 per cent. gave a negative TPI test result. The absolute incidence of BFP reactors in pregnancy is, therefore, but a fraction of 1 per cent.

Though the numbers are extremely small, the consequences resulting from the diagnosis of syphilis-medical, domestic and, perhaps legalmake it imperative that thorough investigations be carried out and that the diagnosis be established beyond dispute before considering treatment. This is now possible with the introduction of such highly specific tests as the treponemal immobilization, fluorescent treponemal antibody, and Reiter protein complement-fixation tests.

An association between carcinoma of the stomach and blood group A was found by Aird, Bentall, and Fraser Roberts (1953). McConnell, Pyke, and Fraser Roberts (1956), investigating blood groups and diabetes, found a considerable excess of group A in men. Pike and Dickins (1954) found a relationship between group $O$ and toxaemia of pregnancy. Buckwalter, Van Scoy, and Knowles (1960), 
Buckwalter, Naifeh, and Auer (1962), Cowan (1962), Hanley (1964), and many others, have also investigated the relation between the ABO blood groups and disease.

Lawrence (1965) has stated that he found rheumatoid arthritis to be four times as common in persons of the $\mathrm{AB}$ group in a population sample in the Rhondda. He mentioned that some American workers have found a deficiency of $\mathrm{AB}$ isoagglutinins in group $\mathrm{O}$ patients with rheumatoid arthritis and in their relatives. All these factors appear to be independent of the rheumatoid serum factor.

The BFP reaction may, perhaps, be due to some constitutional or genetic factor. That the $\mathrm{ABO}$ blood group of a person being genetically determined may show some positive correlation with the BFP reaction, prompted this investigation. The number of chronic BFP reactors available was too small for worthwhile analysis. This paper, therefore, concerns acute BFP reactors only.

\section{Material}

The series consisted of sixty pregnant women, most of whom were referred by the ante-natal clinic for further investigation of positive reactions found on routine serological tests for syphilis.

Their ages ranged from 16 to 41 years-the average being just under 25 years. Ten of the patients were West Indian. All denied any past history of venereal disease and the West Indians denied any past history of yaws.

\section{Management}

All patients were fully examined clinically to exclude syphilis and/or yaws. Serological tests for syphilis were repeated locally and separate specimens of blood were sent to the Reference Laboratory for STS, and RPCF, and TPI tests. The ABO blood group and rhesus factor were also determined.

\section{Results}

In all these patients the RPCF and TPI tests were repeatedly negative. The period required for the serological tests for reagin to become completely negative varied from 15 to 277 days (average 55.7).

The Table shows the number and blood group distribution of the subject sera and controls:

TABLE

\begin{tabular}{c|c|c|c|c}
\hline & $\begin{array}{c}\text { No. in } \\
\text { Blood }\end{array}$ & $\begin{array}{c}\text { Per cent. } \\
\text { in Each Group } \\
\text { Group }\end{array}$ & \multicolumn{2}{|c}{$\begin{array}{c}\text { Per cent. } \\
\text { Distribution }\end{array}$} \\
\cline { 3 - 4 } & & $\begin{array}{c}\text { This Area* } \\
\text { AB }\end{array}$ & $\begin{array}{c}\text { Western } \\
\text { Europet }\end{array}$ \\
A & 25 & $5 \cdot 00$ & $3 \cdot 12$ & 3 \\
B & 3 & $41 \cdot 66$ & $42 \cdot 24$ & 42 \\
O & 29 & $48 \cdot 00$ & $8 \cdot 10$ & 9 \\
\hline
\end{tabular}

* Data supplied by Dr J. Darnborough from data published by Kopeć (1956).

t Keele and Neil (1961).
No difference is seen between the blood group distribution of this area, Western Europe, and the subject sera.

If the ten West Indian patients are excluded, no material difference is found in the distribution of the blood groups.

Rhesus factor distribution was 51 positive (85 per cent.) and nine negative, which corresponds to the national distribution.

\section{Discussion}

Even in this numerically restricted series, any positive correlation in the distribution of blood groups with the acute BFP reactions would be expected to declare itself. None was found. It is very unlikely that a large number would show otherwise.

While this series has, in some measure, cleared the ground in regard to the acute BFP reactors, the problem of the chronic BFP reactors and their ABO groupings remains to be investigated. The number of such reactors available in any one centre is likely to prove too small for satisfactory analysis. The association of such reactions with collagen disease is well recognized, and this, together with Lawrence's observations on the preponderance of the $A B$ group in rheumatoid arthritis, suggests the need for study. A nation-wide approach, perhaps by the British Cooperative Clinical Group, is indicated. Lawrence's work suggests that such a study may give us a clearer idea of prognosis in BFP reactors.

\section{Summary}

A small series of pregnant women with acute BFP serological reactions for syphilis was investigated to find any correlation which might exist between the blood reactions and the ABO blood groups. None was found.

The suggestion is made that a worthwhile study of blood group distribution in chronic BFP reactors should be undertaken.

I thank Dr R. S. Morton, Consultant Venereologist, Sheffield, for his help in the preparation of this paper.

\section{REFERENCES}

Aird, I., Bentall, H. M., and Fraser Roberts, J. A. (1953). Brit. med. J., 1, 799.

British Cooperative Clinical Group (1959). Brit. J. vener. Dis., 35, 162.

Bruck, C. (1911). In "Beiträge zur Pathologie und Therapie der Syphilis", ed. A. Neisser, pp. 343-506. Springer, Berlin.

Buckwalter, J. A., Van Scoy, R. E., and Knowler, L. E. (1960). Brit. med. J., 2. 1643.

-, Naifeh, G. S., and Auer, J. E. (1962). Ibid., 2, 1023.

Catterall, D. (1961). Quart. J. Med., 30, 41.

Cowan, W. K. (1962). Brit. med. J., 2, 946. 
Darnborough, J. (1965). Personal communication.

Detre, L. (1906). Wein. klin. Wschr., 19, 619.

Hanley, W. B. (1964). Brit. med. J., 1, 936.

Keele, C. A., and Neil, E. (1961), "Samson Wright's Applied Physiology", 10th ed., pp. 77-78. Oxford University Press, London.

King, A. (1964). "Recent Advances in Venereology", p. 202, 11. 14-16. Churchill, London.

Kopeć, A. C. (1956). Advanc. Sci. (Lond.), 13, 200.

Lawrence, J. S. (1965). Personal communication.

McConnell, R. B., Pyke, D. A., and Fraser Roberts, J. A. (1956). Brit. med. J., 1, 772.

Moore, J. E. (1956). Brit. J. vener. Dis., 32, 217.

Pike, L. A., and Dickins, A. M. (1954). Brit. med. J., 2, 321.

Wassermann, A., Neisser, A., and Bruck, C. (1906). Dtsch. med. Wschr., 32, 745.
Wilkinson, A. E., and Sequeira, P. J. L. (1955). Brit. J. vener. Dis., 31, 143.

Les groupes sanguins $\mathrm{ABO}$ et les tests sériques de la syphilis donnant des réactions pseudo-positives et biologiques aiguës

\section{RÉSUMÉ}

Un petit nombre de femmes enceintes donnant des réactions sériques pseudo-positives et biologiques aiguës a été étudié afin de trouver s'il pourrait exister une corrélation entre les réactions sériques et les groupes sanguins $\mathrm{ABO}$. Aucune relation n'a été observée.

Il est suggéré qu'une étude pertinente soit faite au sujet de la distribution des groupes sanguins chez celles donnant des réactions pseudo-positives et biologiques chroniques. 